\title{
Stress Testing in Risk Management: An Application in the Turkish Banking Sector
}

\author{
Ismail Yildirım
}

\begin{abstract}
Stress testing is a risk management tool used to simulate extreme but plausible events and measure how the events would impact firm's income. Stress testing aims to identify extreme events that could trigger catastrophic losses in a given portfolio. Here, exceptional refers to events of high severity and plausible excludes improbable scenarios. Stress tests also provide actionable information to senior management for decisions around capital allocation and contingency planning. This paper revealed that the Turkish banking system was robust to a number of adverse shocks.
\end{abstract}

Index Terms - Value-at-risk models, stress testing, market risk, scenario analysis, turkish banking sector.

\section{INTRODUCTION}

Stress testing is an effective tool for improving understanding of economic balance sheets. It is an effective risk management tool with its flexibility and the way it explicitly links potential impacts to specific events [1].

While traditional risk measures provide reasonable information on the behavior of risk factors and their impact on financial institutions in normal business conditions, risk managers need additional tools to test the resilience of their institutions during times of turmoil. Stress tests help identify and analyze the risks which might be latent under benign conditions but, if triggered, could have serious implications for the very existence of a financial institution [2]. Stress tests also provide actionable information to senior management for decisions around capital allocation and contingency planning. [3].

Stress testing attempts to identify the weakest points of a portfolio by pinpointing the crucial risk factors causing the heaviest losses. Stress testing is applied for banks' portfolio by simulating likely worst case scenarios.

Basel Committee attaches particular importance to stress tests. The Committee has the standard stress tests notifications to be issued in the years 1996-2005-2009. In 1996, "The Capital Accord to Incorporate Market Risks Amendment to" internal VaR method in use since the publication of the stress test required to make financial institutions has been made [4]. The results of stress tests of banks wanting to meet the amount of capital allocations "The Application of Basel II to Trading Activities and the Treatment of Double Default Effects" in 2005 after the publication of the stress test results have become more

Manuscript received October 9, 2012; revised November 10, 2012.

I. Yıldırım is with the vocational school, Hitit University, Çorum, Turkey (e-mail: ismailyildirim@hitit.edu.tr ). binding [5].

In addition, the Basel Committee published in 2009, "Revisions to the Basel II Market Risk Framework" ta "Stressed VaR" concept of implemented [6]. "Stressed VaR" destructive actions or events in the financial markets the event of a VaR refers to the value of a bank's portfolio returns[7]. According to the Basel document, one-sided 99\% confidence level, the 10-day holding period and the capital requirement calculated with the daily VaR and "Stressed VaR" is based on the sum of [8]. Financial institutions covered by the Basel II accord on capital adequacy are required to follow these guidelines on stress testing.

Stress testing is designed to explore the tails of the distribution of losses beyond the threshold (typically 99\%) used in Value-at-Risk (VaR) analysis [9]. The advantage of the VAR is that it estimates how write-offs change in the quarters following adverse business cycle shocks implying that the stress test is conditional on the historical correlation among the variables in the multivariate model [10]. Accordingly, stress testing is used increasingly as a complement to the more standard statistical models used for $\mathrm{VaR}$ analysis [11].

The subprime crisis has shown us again that actual shocks in stressed markets are much more severe than historical scenarios. In this paper, we compare stress tests for foreign exchange positions, based on hypothetical scenarios, across a number of VaR methods.

\section{Data And Stress Testing Methodology}

Daily data series spanning the period 2008:6 - 2009:6 is used for the estimation of Parametric VAR model. Net positions of on-balance sheet in foreign currency are considered. For foreign exchange rate risk the net open positions in USD, JPY, GBP as reported by banks are used. 1 year (252 days) EUR, USD, JPY daily changes in exchange rates were taken. As of 25.06.2008 as a variable in other on-balance sheet foreign exchange position of the Turkish Banking Sector taken (see Table I). Other foreign currency positions were analyzed by adding JPY. Turkish Banking Sector Foreign Currency Positions are given in Table I.

In this study, the range of application of the net foreign exchange position of the banking sector is negative.

Stress testing is a tuning process by which we can explore how the portfolio would react to small (Sensitivity Analysis) or more drastic (Stress Tests) changing conditions in the markets. Table II employs this clustering according to the size of the shock to exhibit various forms of stress tests [12]. 
TABLE I: TURKISH BANKING SECTOR FOREIGN CURRENCY POSITIONS

\begin{tabular}{|c|c|c|c|c|c|c|}
\hline Dönem & & EUR & USD & JPY & $\begin{array}{l}\text { Other } \\
\text { FC }\end{array}$ & Total \\
\hline \multirow[b]{3}{*}{$\begin{array}{l}2008 / 0 \\
6\end{array}$} & $\begin{array}{l}\text { Total } \\
\text { Assets }\end{array}$ & 69.527 & $\begin{array}{r}124.45 \\
2 \\
\end{array}$ & 601 & 4.865 & $\begin{array}{r}199.44 \\
6 \\
\end{array}$ \\
\hline & $\begin{array}{l}\text { Total } \\
\text { Liabilities }\end{array}$ & 78.534 & $\begin{array}{r}133.94 \\
7 \\
\end{array}$ & 502 & 4.301 & $\begin{array}{r}217.28 \\
4 \\
\end{array}$ \\
\hline & $\begin{array}{l}\text { Net } \\
\text { balance } \\
\text { sheet } \\
\text { position }\end{array}$ & -9.007 & -9.495 & 100 & 564 & -17.839 \\
\hline \multirow{3}{*}{$\begin{array}{l}2008 / 0 \\
9\end{array}$} & $\begin{array}{l}\text { Total } \\
\text { Assets }\end{array}$ & 73.366 & $\begin{array}{r}124.38 \\
3 \\
\end{array}$ & 978 & 4.897 & $\begin{array}{r}203.62 \\
4 \\
\end{array}$ \\
\hline & $\begin{array}{l}\text { Total } \\
\text { Liabilities }\end{array}$ & 84.553 & $\begin{array}{r}127.19 \\
8 \\
\end{array}$ & 317 & 4.276 & $\begin{array}{r}216.34 \\
4 \\
\end{array}$ \\
\hline & $\begin{array}{l}\text { Net } \\
\text { balance } \\
\text { sheet } \\
\text { position }\end{array}$ & -11.187 & -2.815 & 660 & 621 & -12.720 \\
\hline \multirow{3}{*}{$\begin{array}{l}2009 / 0 \\
3\end{array}$} & $\begin{array}{l}\text { Total } \\
\text { Assets }\end{array}$ & 86.782 & $\begin{array}{r}156.21 \\
6 \\
\end{array}$ & $\begin{array}{r}1.39 \\
0 \\
\end{array}$ & 6.145 & $\begin{array}{r}250.53 \\
2 \\
\end{array}$ \\
\hline & $\begin{array}{l}\text { Total } \\
\text { Liabilities } \\
\end{array}$ & 95.891 & $\begin{array}{r}152.66 \\
2 \\
\end{array}$ & 298 & 5.097 & $\begin{array}{r}253.94 \\
8 \\
\end{array}$ \\
\hline & $\begin{array}{l}\text { Net } \\
\text { balance } \\
\text { sheet } \\
\text { position }\end{array}$ & -9.109 & 3.554 & $\begin{array}{r}1.09 \\
2\end{array}$ & 1.048 & -3.416 \\
\hline \multirow[b]{3}{*}{$\begin{array}{l}2009 / 0 \\
6\end{array}$} & $\begin{array}{l}\text { Total } \\
\text { Assets }\end{array}$ & 84.972 & $\begin{array}{r}143.55 \\
4\end{array}$ & $\begin{array}{r}1.27 \\
1\end{array}$ & 5.605 & $\begin{array}{r}235.40 \\
2\end{array}$ \\
\hline & $\begin{array}{l}\text { Total } \\
\text { Liabilities } \\
\end{array}$ & 92.992 & $\begin{array}{r}147.67 \\
9 \\
\end{array}$ & 318 & 5.036 & $\begin{array}{r}246.02 \\
5 \\
\end{array}$ \\
\hline & $\begin{array}{l}\text { Net } \\
\text { balance } \\
\text { sheet } \\
\text { position }\end{array}$ & -8.020 & -4.125 & 953 & 569 & -10.623 \\
\hline
\end{tabular}

TABLE II: STRESS TESTING METHODOLOGIES

\begin{tabular}{|c|c|c|c|}
\hline Methodology & Forms & Pros & Cons \\
\hline \multicolumn{4}{|c|}{ Sensitivity Analysis } \\
\hline & Incremental & $\begin{array}{l}\text { Flexibility, } \\
\text { automation }\end{array}$ & Local exploration \\
\hline \multicolumn{4}{|l|}{ Stress Testing } \\
\hline & Historical & Actual events & Limited relevance \\
\hline & Customized & $\begin{array}{l}\text { Flexibility, } \\
\text { automation }\end{array}$ & $\begin{array}{l}\text { Resources and } \\
\text { time requirement }\end{array}$ \\
\hline & Reverse & $\begin{array}{l}\text { How to break } \\
\text { down the house }\end{array}$ & $\begin{array}{l}\text { Difficult to } \\
\text { implement }\end{array}$ \\
\hline
\end{tabular}

Sensitivity Analysis typically examines the short-term impact of change in some variable(s) (eg. interest rate, equity prices or a combination of both) on the value of a portfolio/financial position [2].

The risk model used for stress testing need not necessarily have the same features as that used for daily VaR models; indeed it could be argued that there are advantages in using different models for cross-checking purposes. This is almost certainly because many banks use simple unconditional models to estimate VaR. The possibility that bank VaR models are misspecified creates further incentive to ensure that an appropriate model is selected for stress testing purposes. [9]

VaR (Value at Risk) is a method based on the probability of deviation from anticipated profit. Given the banks' open positions, it calculates the potential losses arising to banks from price volatility. Value at Risk (VaR) is the maximum loss not exceeded with a given probability defined as the confidence level, over a given period of time.
This parametric method uses mean and standarddeviation of the distribution of the portfolio for computation of $\mathrm{VaR}$ amount. The model can be formulized as fallows;

$\mathrm{VaR}=$ (Market Value of Port.) (Volatility of Port.) (Confidence Level) (Hold. Period) [13]

$$
\begin{gathered}
=(\mathrm{MV})(\sigma)(\mathrm{CL})(\sqrt{\mathrm{t}}) \\
\sigma_{\mathrm{p}}^{2}=(\mathrm{V})(\mathrm{R})\left(\mathrm{V}^{\mathrm{T}}\right)
\end{gathered}
$$

$$
\sigma_{p}^{2}=\left\{\left(\mathrm{W}_{1} \cdot \mathrm{W}_{2} \cdot \mathrm{W}_{3} . . \mathrm{W}_{\mathrm{N}}\right) \times\left(\begin{array}{c}
\text { Covariance } \\
\text { Matrix...of } \\
\text { portofilio }
\end{array}\right) \times\left(\begin{array}{c}
\mathrm{W}_{1} \\
\mathrm{~W}_{2} \\
\mathrm{~W}_{3} \\
\mathrm{~W}_{4} \\
. . \\
\mathrm{W}_{\mathrm{N}}
\end{array}\right)\right\}
$$

where $V$ is the $(n \times 1)$ vector of weight of each bond, $R$ is the $(n \times n)$ correlation matrix, and $V^{\mathrm{T}}$ is the $(1 \times n)$ transpose of vector $V$ [13].

Position
Exposures $\quad \begin{gathered}\text { Volatilities } \\ \alpha * 2.33=99 \\ \%\end{gathered} \quad \square \quad$ Correlations $=\mathrm{VaR}$

Fig. 1. Parametric VaR (Delta-normal/Varyans-Kovaryans method)

Using Parametric method, Value-at-Risk would be relatively easy to compute, fast, and accurate. Because the method is analytical, it allows easy analysis of the VaR results using marginal and component VaR measures. Parametric methods have their advantages and disadvantages are given Table III [14].

TABLE III: PARAMETRIC VAR ADVANTAGES-DISADVANTAGES

\begin{tabular}{|l|l|}
\hline Advantages & Disadvantages \\
\hline - Fast & - Does not revalue positions \\
- Relatively easy to & - Cannot account for complex or \\
implement & discontinuous payoffs \\
- Requires only portfolio level & - Cannot incorporate multiple \\
sensitivities & time horizons \\
- Can be modified to capture & - Assumes normal or normal-like \\
some measure of convexity & distributions \\
- Data sets are readily & \\
available & \\
\hline
\end{tabular}

In $\mathrm{VaR}$ estimation, a confidence interval needs to be determined in advance. The level, for example 99 per cent or even higher, is determined according to the risk appetite of the institution as well as the amount of its economic capital. Similarly, there is a need to determine the size of shocks, i.e., severity of the scenarios assumed at the beginning of stress-testing.

BIS suggests that market risk computations under VaR models should use 10-day holding period and $99 \%$ confidence level [15]. On the other hand, JP Morgan suggests that 1-day holding period and $95 \%$ confidence level should be used [16].

Basel Committee, banks' market risk VaR figure based on the calculation of capital requirements will not be enough on its own believes [17]. Therefore, the calculated VaR figure, a certain amount of required capital is reached taken bank 
multiplied by the multiplication factor [18]. Basel committee, the multiplication factor is determined as a minimum of 3 [8].

According to the Communiqué about the "Risk Measurement Models and Calculation of Market Risk" [19], which was published on No. 26335 Oficial Gazette dated 3 November 2006, stress test is defined as the all techniques which shall be used to measure the potential endurance of a portfolio against unexpected risks [20]. When we turn back to the applications in Turkey, Banking Regulationa and Supervision Agency ( BRSA) set the rules as below [21]:

$$
\begin{array}{cc}
\text { Confidence Interval } & : 99 \% \\
\text { Holding Period } & : 1 \text { or } 10 \text { days } \\
\text { Historical Observation Period } & \text { : Mostly 1 year }
\end{array}
$$

Fig. 2.VaR parameters according to BRSA

This study employs both $99 \%$ confidence level, and 1-day and 10-day holding period intervals in all VaR computations.

\section{DESCRIPTIONS (FINDINGS)}

Summary statistics of the data given in Table IV. JPY values based on other data used in the analysis of a near-normal distribution (see Table IV).

\begin{tabular}{lrrr}
\multicolumn{4}{c}{ TABLE IV: SUMMARY STATISTICS } \\
\hline & USD/TRL & EUR/TRL & JPY/TRL \\
\hline Mean & 0,00101 & 0,00056 & 0,00164 \\
Median & 0,00007 & 0,00000 & 0,00105 \\
Maximum & 0,0730 & 0,0483 & 0,0963 \\
Minimum & $-0,1125$ & $-0,0655$ & $-0,1626$ \\
Standard Deviation & 0,01573 & 0,01309 & 0,02284 \\
Skewness & $-0,60165$ & 0,02322 & $-0,88466$ \\
Kurtosis & 12,91393 & 3,792309 & 11,25147 \\
Number of Observations & 252 & 252 & 252 \\
\hline
\end{tabular}

Given the distribution of the daily return of the exchange rate charts below (see Fig. 3, Fig. 4 and Fig. 5).

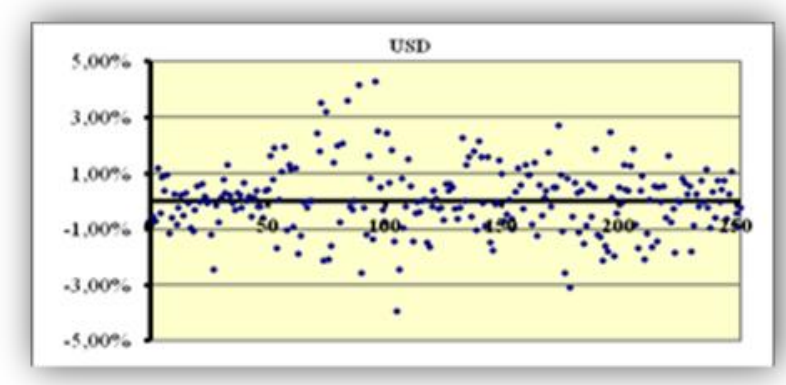

Fig. 3. USD daily changes

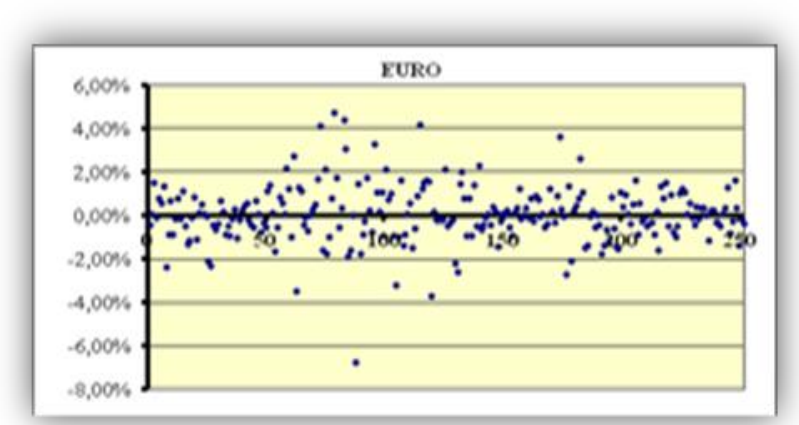

Fig. 4. EUR daily changes

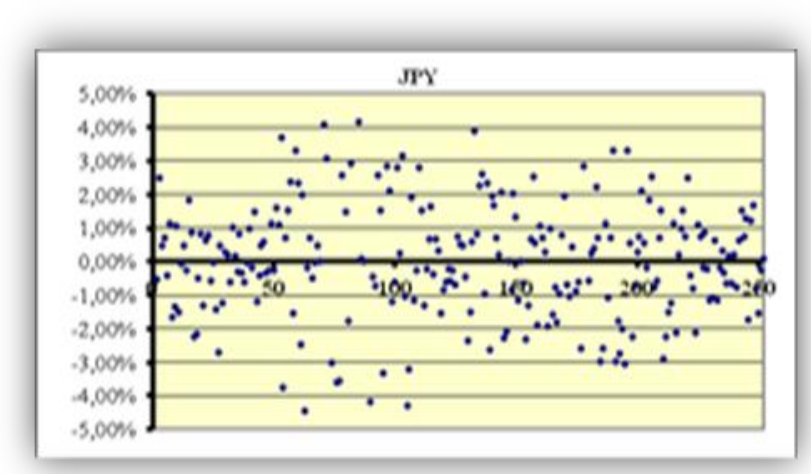

Fig. 5. JPY daily changes

The application results for Parametric VaR are presented in Table V and Table VI. The simulation results are analyzed

\begin{tabular}{|c|c|c|c|}
\hline & USD & EURO & JPY \\
\hline PV (portfolio Value) & 153.026 & 134.632 & 6.320 \\
\hline (Confidence Level) & $99 \%$ & $99 \%$ & $99 \%$ \\
\hline Z Value & 2,33 & 2,33 & 2,33 \\
\hline Retention time ( 1 day) & 1,00 & 1,00 & 1,00 \\
\hline Retention time (10 day) & 3,16 & 3,16 & 3,16 \\
\hline Retention time (1 year) & 15,87 & 15,87 & 15,87 \\
\hline Portfolio Standard Deviation & $1,59 \%$ & $1,31 \%$ & $2,33 \%$ \\
\hline VaR (1 day) & 5.685 & 4.112 & 343 \\
\hline VaR (10 day & 17.976 & 13.002 & 1.085 \\
\hline VaR (252 day) & 90.240 & 65.271 & 5.446 \\
\hline Capital Multiplier (k) & 3 & 3 & 3 \\
\hline Capital Requirement (1 day) & 17.054 & 12.335 & 1.029 \\
\hline Capital Requirement (10 day) & 53.929 & 39.007 & 3.254 \\
\hline Average Adjusted VaR (1 day) & 5.550 & 4.048 & 334 \\
\hline \multicolumn{4}{|l|}{ Total VaR } \\
\hline VaR Portfolio & & 5.646 & \\
\hline \multicolumn{2}{|c|}{$\begin{array}{l}* \text { Effect of Difference of } \\
\text { correlation between }\end{array}$} & 4.493 & \\
\hline
\end{tabular}
by risk type (currency risk) and by currency type (USD, EUR and JPY). VaR value of portfolio at $99 \%$ confidence level and 10-day holding period are about 53 million TRL under Parametric methods.

The above foreign currencies due to the strong correlation between the positive and highly correlated with the effect of reduction in the value of VaR remained low.

The VaR computations for each model are repeated for 99\% confidence level, and 1-day and 10-day holding period except the parametric model (see Table VI).

\begin{tabular}{lrr}
\multicolumn{4}{c}{ TABLE VI: PARAMETRIC VaR } \\
\hline PV (Portfolio Value) & 293.978 & \\
\hline (Confidence Level) & $99 \%$ & \\
Z Value & 2,33 & \\
Retention time (1 Day) & 1,00 & \\
Retention time (10 Day) & 3,16 & \\
Retention time (1 Year) & 15,87 & \\
Portfolio Standard Deviation & $0,82 \%$ & $\%$ VaR \\
VaR (1 day) & 5.646 & $1,9 \%$ \\
VaR (10 day) & 17.855 & $6,1 \%$ \\
VaR (252 day) & 89.633 & $30,5 \%$ \\
Capital Multiplier (k) & 3 & \\
Capital Requirement (1 day) & 16.939 & \\
Capital Requirement (10 day) & 53.566 & \\
Mean Adjusted VaR (1 Gün) & 5.387 & \\
& & \\
\hline
\end{tabular}

Table VII and Table VIII show correlation and covariance matrices for parametric method. 
TABLE VII: CORRELATION MATRIX UNDER PARAMETRIC METHOD

\begin{tabular}{llll} 
Portfolio & USD & EURO & JPY \\
USD & 1,000 & 0,710 & 0,920 \\
EURO & 0,710 & 1,000 & 0,761 \\
JPY & 0,920 & 0,761 & 1,000 \\
\hline
\end{tabular}

TABLE VIII: COVARIANCE MATRIX UNDER PARAMETRIC METHOD

\begin{tabular}{llll} 
Portfolio & USD & EURO & JPY \\
USD & 0,000254 & 0,000148 & 0,000342 \\
EURO & 0,000148 & 0,000172 & 0,000233 \\
JPY & 0,000342 & 0,000233 & 0,000543 \\
\hline
\end{tabular}

Table IX presents the results of the stress testing. The outcomes of the CAR (Capital Adequacy Ratio) and linked with the highest loss of capital value of $\mathrm{VaR}$ is calculated with a factor 3 . The biggest loss in CAR is drawn down 1.84 points.

TABLE IX: STRESS TESTING RESULTS (CAPITAL ADEQUACY)

\begin{tabular}{|c|c|c|c|c|c|c|}
\hline $\begin{array}{l}\text { History of } \\
\text { Financial } \\
\text { Scenarios }\end{array}$ & $\begin{array}{l}\text { Equity } \\
\text { (Million } \\
\text { TRL) }\end{array}$ & $\begin{array}{c}\text { VaR } \\
\text { Result } \\
\text { TRL }\end{array}$ & $\begin{array}{c}\text { Estimated } \\
\text { RWA*** } \\
\text { TRL }\end{array}$ & $\begin{array}{c}\text { Available } \\
\text { CAR**** } \\
(\%)\end{array}$ & $\begin{array}{c}\text { Estimated } \\
\text { CAR } \\
(\%)\end{array}$ & $\begin{array}{c}\text { CAR } \\
\text { deviation } \\
\text { (point) }\end{array}$ \\
\hline $\begin{array}{l}\operatorname{Var} \text { (1-Day) } \\
\text { (1) }\end{array}$ & 99.219 & 5.646 & 515.958 & 19,44 & 19,23 & 0,21 \\
\hline Var (10-Day) & 99.219 & $\begin{array}{r}17.85 \\
5\end{array}$ & 528.167 & 19,44 & 18,79 & 0,65 \\
\hline $\operatorname{VaR}(10-D a y)^{*}$ & 99.219 & $\begin{array}{r}53.56 \\
6 \\
\end{array}$ & 563.878 & 19,44 & 17,60 & 1,84 \\
\hline VaR i & culate & the & l facto & & & \\
\hline
\end{tabular}

\section{CONCLUSIONS}

Stress testing has been part of the risk manager's toolkit for a long time. It is perhaps the most basic of risk-based questions to want to know the resilience of an exposure to deteriorating conditions, be it a single position or loan or a whole portfolio.

Stress testing may be particularly valuable during benign periods when other measures may not indicate emerging risks.

Stress testing is an appealing risk-management tool because it provides risk managers with additional information on possible portfolio losses arising from extreme, although plausible, scenarios. Stress testing approaches and regulatory requirements are going to evolve rapidly.

The summary of results of all VaR models applied at $99 \%$ confidence level and 1-day holding period is presented in Table V and VI. The portfolio VaR values are about 93 million TRL for Parametric method.

Implementation of Basel II compliance in the context of Turkey, studies on stress test carried out quickly and need to be implemented by the Central Bank of the BRSA and studied.

Stress tests by many countries, taking into account the different sizes of their methods or processes are implemented. Countries proposals and the work of international organizations when these applications are to consider.

\section{REFERENCES}

[1] L. J. Guo, ASA, MAAA, Effective Stress Testing in Enterprise Risk Management.

[2] Banking Surveillance Department State Bank of Pakistan, Guidelines on Stress Testing, May, 2012

[3] Oracle Financial Services, "A Practical and Holistic Approach to Stress Testing in Financial Services: Strattegies for Success," An Orancle White Paper, September 2009

[4] Basel Committee on Banking Supervision, 1996, "Amendment to Capital Accord to Incorporate Market Risks," BIS, Basel.

[5] Basel Committee on Banking Supervision, 2005, "The Application of Basel II to Trading Activities and the Treatment of Double Default Effects," BIS, Basel.

[6] Basel Committee on Banking Supervision, 2006, "International Convergence of Capital Measurement and Capital Standards: A Revised Framework Comprehensive Version," BIS, Basel.

[7] Basel Committee on Banking Supervision, 2009a, "Revisions to the Basel II Market Risk Framework," BIS, Basel.

[8] Basel Committee on Banking Supervision, 2009b, "Principles for Sound Stress Testing Practices and Supervision," BIS, Basel.

[9] C. Alexander and E. Sheedy, "Developing a stress testing framework based on market risk models," Journal of Banking \& Finance, vol. 32, 2008, pp. 2220-2236.

[10] G. Hoggarth, S. Sorensen, and L. Zicchino, "Stress tests of UK banks using a VAR approach," Working Paper, no. 282, Bank of England

[11] FBRS Economic Letter, "Stress Tests: Useful Complements to Financial Risk Models," no. 2005-14, June 24, 2005

[12] Romain Berry Stress Testing Value-at-Risk. J. P. Morgan Investment Analytics \& Consulting. [Online]. Available: http://www.jpmorgan.com/tss/General/Stress_Testing_Value-at-Risk/ 1159389400084

[13] J. P. Morgan \& Co., (1996). Riskmetrics - Technical Document. Third Edition. May 26. [Online]. Available: www.riskmetrics.com

[14] 3 VaR Methodologies, Capital Market Risk Advisors, CMRA p.12

[15] BIS, (1996), Overview of the Amendment to the Capital Accord to Incorporate Market Risk, Bank for International Settlements, Basle, January.

[16] J. P. Morgan \& Co., (2001). Return to RiskMetrics: The Evolution of a Standard. [Online]. Available: www.riskmetrics.com

[17] P. Tanriverdi, "Stress Testing "A Simple Stress Testing Application on Turkish Banking System," Yeditepe Universty Graduate Institute of Social Sciences, 2011, İstanbul.

[18] R. Kondapaneni, "A study of the Delta Normal Method of Measuring VaR," A Thesis Submitted to the Faculty of the Worcester Polytechnic Institute, May 5, 2005.

[19] BDDK, "Türk Bankacılık Sektörü Genel Görünümü,” December 2009

[20] BDDK, "From Crisis to Financial Stability (Turkey Experience)," Working Paper, September 2010

[21] BDDK, "Bankalarımız 2009," Yayın No: 267, 2010.

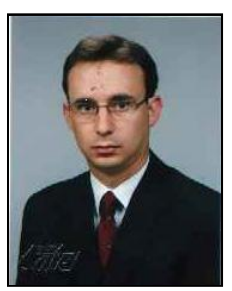

Ismall Yıldırım is Hitit University School of Business Administration Lecturer, Corum was born in 1978, Master degree of Business Administration-Finance Department, Gazi University Institute of Social Sciences, Erciyes University, Institute of Social Sciences Business and Finance doctoral education department continues. Practice Areas: Banking and Insurance, Risk Management, Stress Testing Practices in Insurance Companies 